\title{
INDIVIDUALITY LOST, FUN GAINED SOME RECURRENT MOTIFS IN LATE TWENTIETH- CENTURY ARABIC AND TURKISH NOVELS
}

\author{
Stephan Guth \\ UNIVERSITY OF OSLO, IKOS
}

Starting from an alternative description, based mainly on German literature, of what has come to be called 'postmodernism', the present study reexamines Arabic and Turkish novels from the 1980s and 1990s in the light of this description. It is argued that the descriptive categories developed on the basis of European texts also make sense for texts from the Middle East and North Africa, suggesting that the way life is perceived in these regions at the end of the twentieth century does not differ fundamentally from how it is experienced in a Western country - there is a global discursive community with similar outlooks on life on both sides, rather than a 'clash of civilizations'. The alternative description also assigns many 'postmodern' features their place in a 'structure of meaning', which sheds some new light on the inner architecture of the period in question and on the function of the parts in a complementary whole.

\section{INTRODUCTION}

Instead of the fashionable label 'postmodernism,' Walter Falk, a professor of German literature who tried to trace general trends in German as well as in world literature since the early 1980 s, found another, perhaps rather curious term to characterize this period. He tentatively called it 'Malism' (Malismus), a word derived from the Latin malum, i.e., the 'evil'. ${ }^{1}$ Falk chose this term because he identified the 'Evil' (in a very broad sense of the word) as being at the root of a trinary structure ${ }^{2}$ com-

\footnotetext{
${ }^{1}$ Cf. Walter Falk, 'Das Sinnsystem der gegenwärtigen Periode: Präzisierungen der bisherigen Deutung (Zusammenfassung)', paper presented at the annual meeting of the MKE (Marburger Kreis für Epochenforschung), 16 Sept. 1996, fol. 3 .

${ }^{2}$ For the underlying theory of the trinary structure of 'meaning' and the corresponding method of literary analysis cf. Walter Falk, Handbuch der literarwissenschaftlichen Komponentenanalyse: Theorie, Operationen, Praxis einer Methode der neuen Epochenforschung (Frankfurt/Main, etc.: Lang, 1983); new rev. edition under the title Handbuch der Komponentenanalyse: Erschließen von Sinn in Text und Epoche (Taunusstein, etc.: Vlg. Werner Imhof, 1996). A short introduction to basic concepts of 'componential analysis' is also available
} 
mon to all the texts he had studied. The most important, and hence eponymous, structural component of Malistic texts, he says, is the hero's confrontation with what can be described metaphorically as a 'house', which in former times had offered the security and warmth of a home, but is now lying in ruins, destroyed by some 'evil' forces, which in most cases have something devilish about them and sometimes even become personified as Satan himself. The second component, in a way the antithesis of the actual situation of 'destroyedness' faced by the heroes, consists of a kind of 'treasure' which they detect among the 'ruins', a 'treasure' that obviously has survived all destruction undamaged and therefore occupies the place of Potentiality in the Falkian PAR (potentiality-actuality-resultativity) structure. The third component - we may well call it a synthesis - comprises the results of the heroes' efforts to raise the Treasure from among the Ruins, against the forces of the Evil. ${ }^{3}$ (See table 1, next page.)

Beginning with the nineteenth century, all Middle Eastern literatures have undergone, with increasing intensity, a process of progressive integration into the global course of literary developments. ${ }^{4}$ This is why I am convinced that Falk's characterization of post-1980 German (and much other) literature as 'malistic' is applicable also to Turkish and Arabic (and probably also Persian, Urdu and many other) texts. In the following I will try to show that the texts I have chosen (rather arbitrarily) ${ }^{5}$ may indeed be interpreted as fitting into Falk's pattern. Thus, I hope to make the findings of a scholar of German literature serve a threefold end:

a) to supply us with new aspects that may help to modify the description and to improve our understanding of a number of phenomena in Middle Eastern literatures that we have been observing and trying to

on the MKE website (unfortunately in German only): $<\mathrm{http}: / /$ www.walterfalk.de/Wissenswertes/wissenswertes.html>.

${ }^{3}$ Cf., esp., Walter Falk, Die Ordnung in der Geschichte: Eine alternative Deutung des Fortschritts (Sachsenheim [etc.]: Burg Vlg., 1985); briefly summarized, e.g., in id., Václav Havels Briefe aus dem Gefängnis: Wo der Mensch zu Hause ist - ein Dialog (Taunusstein: VerlagMar, 1994), 240ff.

${ }^{4}$ This process is described in detail (for the Turkish and Arabic novel) in my Brückenschläge: Eine integrierte 'turkoarabische' Romangeschichte (Mitte 19. bis Mitte 20. Jhdt.), and in a summary version in my 'The Simultaneity of the Non-Simultaneous: The Global Dimensions of Middle Eastern Literature (esp. in the 19th Century)'. See 'References'. (Bibliographical information not given in the footnotes is provided either in 'The Texts' or 'References' below.)

${ }^{5} \mathrm{Cf}$. the list at the end of this article. 
make sense of during the last two decades,

b) to provide an instrument of ordering and grouping hitherto isolated

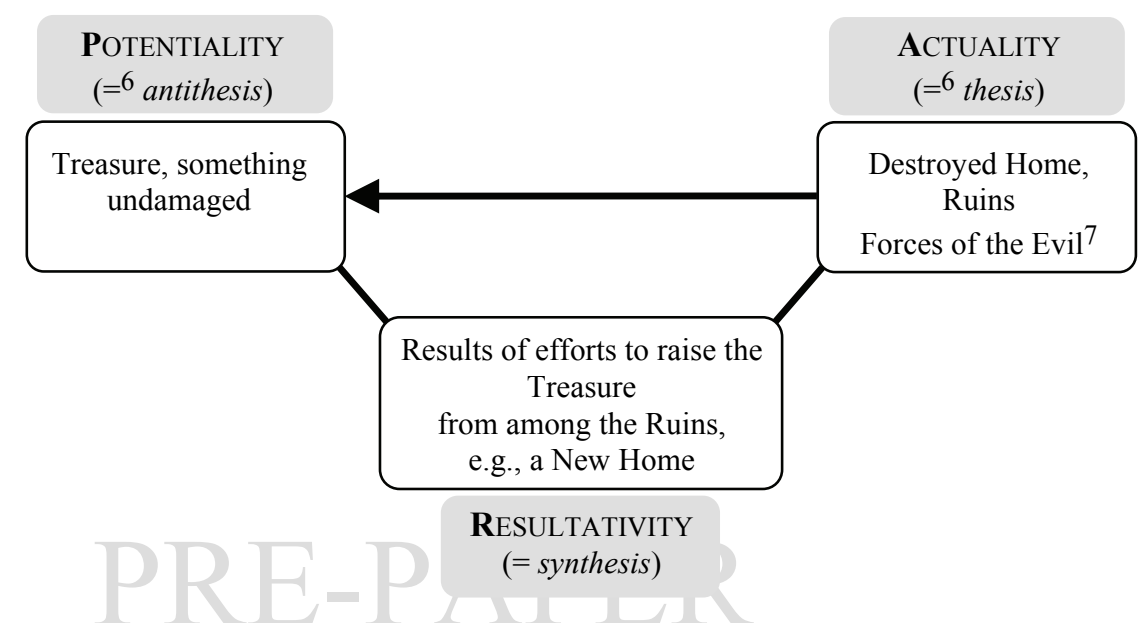

Table 1. PAR structure of meaning in texts of the Malistic period (1980 ff.) according to W. Falk

data and insights under one heading, under a system which at the same time allows assigning the manifold elements of meaning their specific

${ }^{6}$ Actuality can be equated with the thesis only in periods to which can be ascribed what Falk terms 'priority' over Potentiality, i.e., where the manifestation of Potentiality comes as an answer to the appearance of Actuality. There are periods in which the stimulating impulse is on the part of Potentiality and Actuality is the secondary component, making itself felt as an obstructing force only antithetically, in a reaction to the appearance of a Potentiality that has made itself felt earlier. For details see Falk, Handbuch, 140-41 and 183. The 'priority' of Actuality, not of Potentiality, in the period under consideration here (1980-) is also the reason to name it after the main force of its Actuality, the 'Evil'. In the diagram, the 'priority' relation is expressed by an arrow (read: the Destroyed House is prior to the discovery of a Treasure, or: the discovery of a Treasure comes as an answer to the suffering under actual circumstances that are experienced, as the loss of a Home, etc.).

${ }^{7}$ In a paper given at the 1997 annual meeting of the MKE group ('Die Wiederentdeckung christlicher Problemzusammenhänge in der deutschen Dichtung seit 1980', fol. 1), Falk recommended replacing some of these terms by more general ones representing a higher level of abstraction. As I found these new terms ('das Urböse', 'Blockiertheit der Neuerung', 'Geschwächtheit des Bergenden') almost untranslatable, I decided to stick to the older terminology, the metaphoric imagery of which is moreover more lively and expressive. 
place within the whole, ${ }^{8}$

c) to give further evidence of the long-ignored fact of the integration of Middle Eastern literatures into global processes, evidence which will become apparent with the very applicability of Falk's system to Middle Eastern literatures.

In order to illustrate my assumption and to prove this applicability with concrete examples, I have selected one of the undoubtedly most recurrent motifs of late twentieth-century Arabic and Turkish literature the loss of an individual identity, i.e., the destruction of the 'self'. It goes without saying that this loss can easily be identified with the Malistic image of the Destroyed Home. Juxtaposed to it there is, among others, the equally frequent motif of fun running through contemporary Middle Eastern literature. Here, as in German literature, fun results from the hero's efforts to raise a Treasure from some kind of Ruins. Concentrating on images and representations of the Destroyed Home, respectively Treasure and Fun types, i.e., on the metaphors and plot allegories the authors use to convey a certain experience or stance, will allow us to look a bit deeper into the psycho-emotional dimension of the 'loss of identity' complex as well as the elements by which they become counterbalanced.

\section{INDIVIDUALITY LOST - THREATENING HELLS}

In some Arabic and Turkish texts of an early, initial stage of Malism, the Malistic forces of Actuality may, however, still be experienced by the writers as so strong and overwhelming that a Treasure cannot yet be discovered at all or that its existence is at best sensed somehow unconsciously. This is the case, e.g., in Jabrā Ibrāhīm Jabrā's al-Ghuraf al$u k h r \bar{a}$ (The other rooms; 1986), a novel that has been described as a 'convincing parable of the loneliness and forlornness' of the individual in modern societies and a faithful expression of his suffering. ${ }^{9}$ As in German texts of early Malism, here too there is still absolutely no fun or happy ending; we only have already a number of images of a Destroyed

\footnotetext{
8 The holistic and systematic character of my Falkian approach will also be a feature that distinguishes it from studies of Postmodernism in Middle Eastern literatures, valuable as they may be in themselves, like Arabische Literatur, postmodern, a collection of essays edited and preceded by a well-informed introduction from the pen of Andreas Pflitsch (Munich: edition \& kritik, 2004).

9 Jacket text (in my translation) of the German translation of al-Ghuraf al$u k h r \bar{a}$ (see 'The Texts' at the end of this article). Cf. also Hartmut Fähndrich, 'Nachwort', ibid., 135 (see 'References', below).
} 
Home which we will encounter later also in the Fun Gained texts, in which fear and sometimes panic vis-à-vis the catastrophe of destruction will become somewhat balanced by more positive forces and often even more optimism. In Jabrā's novel these notions are still absent. It opens with the hero standing alone at night on a large square that

lay there void, lonely, and deserted, forgotten by God and man. It was as if nobody was left in town who would still move, fight, or love, as if a plague had descended upon it and spared nobody (Ghuraf, 7). ${ }^{10}$

The destruction of the Home here basically consists of its desertedness. ${ }^{11}$ In this situation, the first satanic figures appear in the text: e.g., a man wearing a black coat reaching down to his ankles, or a very beautiful woman, a satanic temptress and seductress, or siren, ${ }^{12}$ who invites him to follow her into an ominous large building (the description of which reminds me of the nightmarish Mugamma ${ }^{\mathrm{c}}$ complex on Cairo's Tahrīr Square, but may of course easily have been modeled on some Security headquarters in an Arab country, or even the notorious Ljubljanka). In that building he is being led - it does not become clear whether by some secret plan or by mere chance - from one room into another. The labyrinth-like topography of the space in this novel resembles the Hells of many other Malistic texts. Several devilish persons make their appearance in ever-changing masks and prevent the hero from defining, or remembering, who he is. They force upon him identities which he tries to refuse but cannot counter with an identity of his own, since the deeper he gets drawn away by the Devils into the depths of the Labyrinth the less certain he becomes about his own self. ${ }^{14}$ When he looks into the mirror he faces another person, with a moustache and grey temples (Ghuraf, 20), and when he searches his pocket for an identity card he finds not only one, but a whole stack of such cards, all issued for different names and professions (cf. Ghuraf, 84). Besides this 'loss of

\footnotetext{
10 Translation mine.

${ }^{11}$ Here and in what follows I am italicizing those features that are characteristic of one of the Malistic components.

12 Significantly, the figure of a siren had a great appeal also for a German author writing at the beginning of the 1980s. In Die Sirene (The Siren) (Cologne: Kiepenheuer \& Witsch, 1980), Dieter Wellershoff decided to base the whole novella on the plot of an encounter between the hero and a 'siren' who slowly lures him to (self-)destruction.

${ }^{14}$ Cf. Fähndrich, 'Nachwort', 134-35.
} 
identity' theme the novel presents still another element that is repeatedly found in Malistic texts: an increasing confusion about what is real and what is only imagined, i.e., a blurring of boundaries between reality and fiction. In a scene close to the novel's end, the hero experiences a moment of happiness because he starts to remember details from the past and, together with those fragments of his personal history, thinks he has started to regain his lost identity (Ghuraf $87 \mathrm{ff}$.). Only a few moments later, however, he happens to pass by a table on which a book entitled The Alternative is lying, and when he opens it he comes to read there word by word, as part of the printed text, exactly those thoughts he had been pondering in his mind just a few minutes ago! The undecidedness between a 'real' existence and an existence as the product of some unknown author, i.e., the doubtfulness of an identity even in its ontological status, or its being perhaps nothing but a copy of something else, has a very frightening effect in Jabrā's novel: the hero suffers a heavy blow, he almost goes mad, and only very slowly does his panic calm down. Nevertheless, a way out of this hell of confusions does exist, the hero finally finds himself outside the labyrinth. He is, however, not very happy about that, and rightly so - it is by no means clear whether his escape is 'real' or only 'virtually real'. The program for the next night given to him by people waiting at the exit is exactly what he already went through during the past night. Past and future in this way melt into one, with no orientation possible anymore since even Time has lost its direction. ${ }^{15}$

15 A very similar 'Kafkaesque' atmosphere is evoked already half a decade earlier in Șuncallāh Ibrāhīm's al-Lajna (The Committee; 1981), with less ontological-existential distortion perhaps, but with a description of the Committee's headquarters and a characterization of the Committee members which in its scurrility and diabolism come very close to that of Jabrā's text. (N.B. Translated titles in italics are those of published translations know to me at the time of writing that are roughly equivalent to the original title.) For further references, cf. the chapter on al-Lajna in my Zeugen einer Endzeit (Berlin: Schwarz, 1992). An equally pessimistic tone dominates almost all early Malistic texts. In some of them, distorted identity may not yet be a major element of the Actuality layer (although the identity problem may be 'in the air' already); cf., e.g., Hanān al-Shaykh's Hikāyat Zahra (The Story of Zahra; 1980), where the part of the Devil is played by a sniper during the Lebanese civil war. This man is not only cruel but also exercises a strange, yet irresistibly strong attraction on the heroine (in that he is clearly one of the Tempters/Sirens we have already met in several other texts), and this attraction causes a development within the woman's personality that may be interpreted as a challenge to her identity. In 
A similarly frightening text in Turkish literature with still almost no indication of a hidden Treasure is, for example, Bilge Karasu's Gece (Night; 1985). ${ }^{16}$ Priska Furrer has characterized this text as a novel of rejected coherence. ${ }^{17}$ In it

[e]ven the most assiduous attempts to attribute coherence to the text end in new contradictions and futility. Who wants to murder whom, and why? Who, in the end, remains alive, and who has penned which texts? Do the four figures in the novel, the four who write as 'I' and whose texts we read, really live in the novel's world or are they merely inventions of one of the others, and if so, of whom? Is it impossible to unravel the puzzle satisfactorily because one of the 'I's writing here is lying for the purpose of political manipulation? Or are we dealing with a case of insanity, with a sole figure (which one?) suffering from a personality with multiple fractures? ${ }^{18}$

In this novel, the relation between two major thematic focuses of our texts, the 'loss of an individual identity' in a labyrinth-like world and the diabolic 'reality-fiction' confusion ${ }^{19}$, becomes a bit clearer as in Jabrā's Ghuraf or Suncallāh's Lajna. The text urges the reader to try to unmask

Gamāl al-Ghītān̄̄'s Risālat al-bașāoir fì 'l-mașāo ir (The epistle of insight into destinies; 1989), the Destroyed Home of Actuality is represented in the whole of present-day Egypt. The Devils here make their appearance as pedophile Arabs from the Gulf, as Egyptian entrepreneurs of the new infităh class and unscrupulously capitalist exploiters, etc. In most of the many separate stories told in this text, identity, too, is at stake; cf. my Zeugen einer Endzeit, 150-99, 226-94. In both Orhan Pamuk's Sessiz ev (The silent house; 1983) and ' Abduh Gubayr's Tahrink al-qalb (Moving the heart; 1982), a decaying house is at the center of interest (in Pamuk's novel already in the title!). For Sessiz ev, cf. Yasemin Karakaşoğlu's study Fünf Stimmen im lautlosen Haus: Geschichte, Zeit und Identität im türkischen Gegenwartsroman am Beispiel von 'Sessiz Ev' von Orhan Pamuk (Wiesbaden: Harrassowitz, 1993); for a comparison between Sessiz Ev and Tahrīk al-qalb, see my 'Zwei Regionen - eine Literaturgeschichte?' (Die Welt des Islams 34 (1994), 218-45).

${ }^{16}$ For a study of this novel, cf. Priska Furrer, 'Readers as Writers, Fiction as Theory, and Other Confusions: The Metafictional Trickery of Bilge Karasu and Pınar Kür', in S. Guth, P. Furrer, and J. C. Bürgel, eds., Conscious Voices: Concepts of Writing in the Middle East (Beirut: Orient-Institut; Stuttgart: Steiner, 1999), 51-68; for Gece, see esp. 57ff.

${ }^{17}$ Ibid., 57.

18 Ibid., 60.

${ }^{19}$ Note that the words 'devil' and 'diabolic' go back to the Greek verb diabállein 'to throw (-ballein) apart (dia-)', a diábolos thus being 'one who turns upside down, confuses, deceives, slanders'. 
concealed identities, but in doing so makes clear that identities are not reliable facts, but ideological fabrications that serve only those in power. Fiction is thus seen as an 'instrument of power' 20 which, by deluding people into believing in the reality of, say, a Turkish national identity, makes it possible to rule over them. ${ }^{21}$ The fatal, but in a way also highly ironical, consequence is that in adopting such an ideologically fabricated 'true' identity that ensures you of your individuality vis-à-vis the Other, you loose your real identity and in fact become de-individualized.

Both Karasu's Gece and Jabrā's Ghuraf apparently follow the same path of deconstructing firmly established certainties and formerly wellaccepted identities (= the Homes that are seen as destroyed in Malism), and they do so, it seems, in order to open the way for what would be the next step: the discovery of an individual self which would really be one's own. And this is indeed what happens in the 'Fun Gained' texts to which I am turning now, although the solution of the identity problem they offer is rather surprising: real individuality, according to them, consists in an acceptance of your unindividuality, a fragmented self made up of multiple identities. In his famous Kara kitap (The Black Book; 1990), ${ }^{22}$ Orhan Pamuk, among many other 'tales', tells the story of a young prince who wanted to be solely and purely himself. ${ }^{23} \mathrm{He}$ tried to rid himself of all that could negatively influence him and corrupt his individual self, by systematically banning all external influences - teachers, books, furniture, everything - only to find that in the end there was

20 Furrer, 'Readers as Writers', 65.

21 The 'faked reality' idea lies at the core of Suncallāh's Lajna. There, however, the hero is still sure of his own identity and only tries to unmask the false identity of those in power. Judging from the hero alone, Lajna may therefore not be considered an 'individuality lost' text. Cf., however, what will be said below when discussing the 'false world' and 'adulterate identity' theme again.

${ }^{22}$ For a collection of newspaper articles, critiques, commentaries on, and studies of, this novel, cf. Nüket Esen, ed., Kara kitap üzerine yazllar (Istanbul: Can, 1992). For an investigation within the framework of Turkish postmodernism (with many suggestions for further reading), cf. Mark Kirchner, '»Das Schwarze Buch «, Orhan Pamuk und die türkische Postmoderne', in Konrad Meisig, ed., Orientalische Erzähler der Gegenwart: Vorträge und Übersetzungen der Mainzer Ringvorlesung im Sommersemester 1998 (Wiesbaden: Harrassowitz, 1999), 43-63. For a comparison with the Egyptian writer Șun callāh Ibrāhīm's novel al-Lajna, cf. my A World Full of Secrets: The Hero as Detective in Two Novels from Egypt and Turkey (see 'References').

23 Pamuk, Kara kitap, chap. 16 ('Şehzadenin hikâyesi', 386-404). 
nothing left at all! The search for an all-exclusive individuality, we have to conclude, just leads to nothing. ${ }^{24}$ Accepting yourself as a composite being, however, frees you from the burden of having to search for a fixed and definite identity and of committing yourself to the tight and almost strangling corset of an ideologically prefabricated self. With the freedom you gain by accepting yourself as a composite being you also gain fun, because only now will you be able to live life truly and wholly, with all its fascinating aspects, no more having to suppress any of the elements of your self, of whatever origin they may be.

This solution, together with its destigmatizing and taboo-lifting effects, has of course political, psychological, sociocultural as well as literary dimensions, all of which are dealt with, alone or in varying combinations, in the 'Fun Gained' texts. All of them start out with frightening pictures of a lost identity that are very similar to those of Karasu's Gece and Jabrā's Ghuraf, or other texts of early Malism in general. The realization that the warming and securing Home of an individual identity and of a reliable reality has been destroyed may be experienced as paralyzing at first, but the heroes then soon set off to search in the ruins of that Home for something that has remained undamaged. For this search, the plot-pattern of a journey is frequently used, and very often it is a journey through some kind of desert, through a labyrinth, or a hell. In his Kara kitap, for instance, Orhan Pamuk lets the hero search for his wife and her half-brother, who have both disappeared, in the labyrinths of his home town, Istanbul, the dynamics of the major parts, if not of the whole text developing from the drive and energy inherent in the underlying nucleus of the 'search' plot. His next novel, Yeni hayat (The New Life; 1994), again is constructed essentially as a journey the hero undertakes on rotten busses having accidents every now and then, through an 'apocalyptic scenery' of Anatolian provincial towns 'ruined by modernity'. ${ }^{25}$ Nedim Gürsel, too, in his Illk kadın (The first woman; 1983)26 sends his first person narrator onto an expedition, again through Istanbul, but also through his own memory, just as Edward al-Kharrāt lets his protagonist wander through his home town Alexandria and, at the same time, the memory of his past, in Turābuhā zacfarān (City of Saffron;

${ }^{24}$ Cf. Kirchner, '»Das Schwarze Buch «', 61.

25 Ibid., 50.

${ }^{26}$ First published in the collection Kadinlar kitabl (see bibliography, 'The Texts'). Illk kadın was translated into French by Anne-Marie Toscan du Plantier under the title La première femme (Paris: Du Seuil, 1986), and into German by Eva Warth-Karabulut, Die erste Frau (Frankfurt/M.: Dağyeli, 1986). 
1985), ${ }^{27}$ both heroes seeing themselves standing before some kind of ruins. In the case of Kharrāt's Mikhā̄ $\overline{1}$ l this is his own life, but also the actual state of affairs in the world around him; he feels threatened by the transitoriness and finiteness of human life (cf. Turābuhā, 2nd ed., 125) and imagines himself balancing at a 'fragile, parlous edge, between being and nothingness' 28 (ibid., 126), where he has visions of shäti ${ }^{\circ}$ almawt 'the shores of death' (ibid.). In a similar situation is also the heroine of Tahar Ben Jelloun's La nuit sacrée (The Sacred Night; 1987), ${ }^{29}$ who had been forced by her father into the 'hell' of a male identity and been brought up as the son Ahmed he could be proud of. After the death of the father - the patriarchal ruler who ruled with the help of an ideology (= a kind of fiction), but of course also one of the many Satans to be met with in this story (see below) - Ahmed changes his name to Zahra and sets out on a journey full of adventures searching for his/her identity. And it is, of course, not astonishing that the idea of living in a false world with an adulterate identity is to be found also in texts by Islamist authors such as, e.g., Ali Nar, the former head of the Turkish section of the Rābitat al-Adab al-Islämī al- ${ }^{c} \bar{A} l a m i y y a$, the World League of Islamic Literature. In his novel Arllar Ülkesi (The bee country; 1994), the formerly paradise-like Isle of the Bees has become invaded by malicious snakes, the inhabitants of the neighboring 'Devil's (!) Island' (Iblis adast). The snakes, with the help of camouflage and other fictional methods, including a re-writing of the country's history, a contamination of language and other means of brain-washing through ideological propaganda, have not only changed life into hell on earth for the bees, but also have made them forget who they really are. Although this novel is not explicitly built as a journey through a country or a city, the motif of 'journeying' is present at least metaphorically in that the reader is lead

\footnotetext{
${ }^{27}$ For studies of this novel, cf. esp. Magda al-Nowaihi, 'Memory and Imagination in Edwar al-Kharrat's Turābuhā za'farān,' JAL 25 (1994): 34-57, and Andreas Pflitsch, 'Narration against Transitoriness and Temporality: Mythical Time Structure in Idwār al-Kharrāț's Works,' in Angelika Neuwirth et al., eds., Myths, Historical Archetypes and Symbolic Figures in Arabic Literature: Towards a New Hermeneutic Approach (= Proceedings of the International Symposium in Beirut, June 25th - June 30th, 1996) (Beirut: Orient-Institut; Stuttgart: Steiner, 1999), 363-78 (with comprehensive bibliography).

28 'alā hädhihi 'l-häfati 'l-hashshati 'l-qaliqati, bayna 'l-hayāti wa'l-cadami.

${ }^{29}$ Cf., also for further references, Kindlers Neues Literatur Lexikon, ed. Walter Jens, Studienausgabe der Originalausgabe 1988-92 (Munich: Kindler, [n.d.]), 2: 503-4, s.v. 'Ben Jelloun'.
} 
through different sectors of the bee society (and of the bee island), a 'journey' that parallels the concrete journeys of the other texts just mentioned because this one, too, covers the whole space of the Destroyed Home and it is the aimless wandering about and rummaging around in the Ruins from which the forces of Potentiality emerge.

One need not be an Islamist, however, to feel that identity and individuality have been destroyed by foreigners and/or their collaborators. Șun ${ }^{c}$ allāh Ibrāhīm and Latife Tekin, for instance, both very secularist leftist authors, embark in their works on similar journeys, this time through the everyday culture of the masses that in Egypt as well as in Turkey is shaped and controlled in every respect by a powerful politicoeconomic oligarchy that has monopolized production and power; $\mathrm{cf}$. Șuncallāh Ibrāhīm's al-Lajna (n. 15) and Dhāt (Zaat; 1992), or Latife Tekin's Berci Kristin çöp masalları (Berji Kristin: Tales from the Garbage Hills; 1984). In Lebanon, it was civil war that destroyed the Home, and together with horrific memories of the 'Events' many other memories of the past, i.e., history, have been suppressed after the war ended. This is why the narrator in Ilyās Khūrî's Rihlat Ghāndī al-șaghīr (The Journey of Little Gandhi; 1989) has some difficulty obtaining information about who 'Little Gandhi' was. Together with the history of the life of the little shoeshine boy, the boy's identity lies 'in ruins', and again the novel - which essentially represents an attempt to reconstruct the lost identity - is organized as a 'journey', this time a journey from one informant to the next. The stops on this journey are the stories the narrator is told by the people he meets, and this pattern in its turn is used in many other texts, e.g., Gamāl al-Ghīțānī's survey of life in Sadat's Egypt, Risālat al-bașā ir fì 'l-mașā ir (n. 15). In an earlier novel of al-

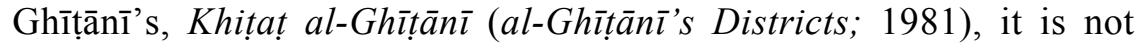
stories that represent the stops on a journey; instead, the jigsaw puzzle of identity is put together by visiting many places and journeying through many districts, the 'journey' becoming a kind of historico-topographical survey (as may be guessed already from the books title ${ }^{30}$ ).

In all these texts, still numerous devilish figures and/or forces, resembling those of early Malistic texts like Jabrā's Ghuraf or Karasu's Gece, make their appearance. They may take on the mythology-loaded form of snakes, as in Ali Nar's Artlar ülkesi, here standing for a foreign invader

${ }^{30}$ Khitat al-Ghịtāni alludes to the famous Khitat ${ }^{c}$ Alī Mubārak, i.e., al-Khitat al-jadīda al-Tawfíqiyya by ${ }^{\mathrm{C}} \mathrm{Alī}$ Mubārak (1823-93) which in its turn was 'intended to be a modern counterpart of al-Makrīzī's Khitat' $\left(E I^{2}, 1: 396\right.$, s.v. ‘cAlī Pāshā Mubārak' [K. Vollers]). 
and imperialist domination; ${ }^{31}$ they may be ominous callers with strange names like Mahir İkinci (Mahir Second) or Mehmet Üçüncü (Mehmet Third) as in Pamuk's Kara kitap, who of course belong to the Siren/Tempter/Seducer type already encountered above. In Kharrāṭ's Turābuhā zacfarān, it is Death and Time who play the role of the diábolos, ${ }^{32}$ threatening everything and everybody, not only with physical extinction, but also with falling into oblivion, i.e., with extinction in the memory of others. In Ben Jelloun's L'enfant de sable (The Sand Child; $1985)^{33}$ and its successor, La nuit sacrée, the Devil is an almighty father. Devils very often also appear in a shape resembling the heroes' own shape, e.g., in Pamuk's Beyaz kale (The White Castle; 1985), ${ }^{34}$ where a Venetian scholar, who has been captured and brought to the Ottoman court, encounters a hoca there who is the spitting image of himself, or as in Kara kitap, where a painter who instead of doing a piece of art of his own in a competition just fixes a mirror on the wall facing his rival's painting, so that no one can decide which of the two panoramic views of Istanbul is more beautiful, the original one or its reflection in the mirror. ${ }^{35}$

The 'satanic' role of a dominant Preventer of identity/individualityfinding is very often bestowed also upon eminent figures of the cultural, especially the literary heritage, because the (post-) modern artist is willy-

31 The cultural revolution which the Snakes impose on the Bees is openly likened to the innovations decreed by Atatürk for the new Turkish Republic and is described just like the process of brain-washing for which in modern Arabic the expression ghazw fikri, or 'intellectual imperialism', has become widely used. In the novel old customs are abolished and replaced by strange new ones, e.g., in music and dancing, a new writing system is introduced in order to prevent the subjects from reading their old scriptures, and from a certain point of time on the Bees have to wear hats - details which make the reader think immediately of the so-called Hat Revolution of 1925, when Turkish men were forbidden to wear their traditional headgear and ordered by law to replace it by the European hat; or the reform of the writing system which, in 1928, adopted Latin instead of Arabic characters, thereby cutting the Turks off from their Ottoman history. Another recurrent element is the contamination (= destruction) of language (= home) by interspersing it with words from the language of the colonizer/imperialist.

${ }^{32}$ Cf. supra, n. 19.

33 Cf., e.g., Kindlers Neues Literatur Lexikon, s.v. 'Ben Jelloun', 2: 502-3, with further references.

${ }^{34}$ Cf. ibid., s.v. 'Pamuk', 12: 920-21.

35 Pamuk, Kara kitap, chap. 14 ('Esrarlı Resimler'), 367-71. 
nilly only a successor to his predecessors, whom he cannot but refer to, and thus has to copy, in one way or the other. The 'devilish' function is, however, very frequently also performed by writer figures within the narratives, who, out of hubris, aspire to the God-like position of a creator, because, with the help of fiction, they create Reality and are sufficiently mighty to impose it on the readers, pulling out all the stops in order to prevent them from unmasking this 'reality's' purely fictional character. ${ }^{36}$ Examples of this phenotype of Satans are to be found, e.g., in Pınar Kür's Bir cinayet romanı (A crime novel; 1989) ${ }^{37}$ and Ahmet Altan's Dört mevsim sonbahar (Autumn throughout the year; 1982) ) $^{38}$. In both works, the authors-within-the-story model everything according to their own desire, taking pleasure even in arranging their creatures' deaths.

Because of the crime-like character of the Satans' deeds, because of the mysteriousness of their appearances and the difficulty of the search within the Destroyed Home, etc., many texts also display the features of crime or detective novels, as is the case, e.g. (again), with Pamuk's Kara kitap, or with Pınar Kür's Bir cinayet romanı, which carries the 'crime' (cinayet) already in its title. ${ }^{39}$

${ }^{36}$ Referring to Stuart Hall's 'The Rediscovery of "Ideology": The Return of the Repressed in Media Studies', in Michael Gurevitch et al., eds., Culture, Society and the Media (London, 1995 [1st ed. London \& New York: Methuen, 1982, 56-90]), Erhard Reckwitz shortly/characterizes the so-called 'reality effect' as follows: 'In einem erweiterten gesellschaftlichen Sinn verwendet [...] St. Hall (1982) den Begriff "reality effect" als Synonym für Ideologie, die sich dadurch auszeichnet, daß scheinbar konstative Aussagen über "how things really are" ihren performativen Status als gesellschaftliche Vorurteile zu verschleiern suchen. Bes[onders] im modernen und postmodernen Roman wird durch spielerische Hervorkehrung des selbstreferentiellen Konstruktcharakters des Kunstwerks [...] dieser ideologischen Naturalisierung entgegengewirkt.' Cf. entry 'Realismus-Effekt' in Ansgar Nünning, ed., Metzler Lexikon Literaturund Kulturtheorie: Ansätze, Personen, Grundbegriffe (Stuttgart; Weimar: J. B. Metzler, 1998), 453-54, here 454.

${ }^{37}$ Cf. Furrer, 'Readers as Writers', esp. 52ff.

${ }^{38}$ Cf. my 'Post-Modernism, Apoliticality, "Settling Accounts": On Ahmet Altan's Dört mevsim sonbahar', Conscious Voices, 107-19.

${ }^{39}$ Some texts of early Malism, too, carry such traits, e.g., Suncallāh Ibrāhīm's al-Lajna. A crime-infested atmosphere is created also in Jabrā's and 'Abd al-Raḥmān Munīf's 'Ālam bi-lā kharā'it (A world without maps; 1982), in which light should be brought 'into several strange and frightening incidents that have all taken place in an imaginary, yet very real present-day Arab city'. Fähndrich, 'Nachwort', 132. 
Facing the ruins of the Destroyed Home or exploring on their journeys the depths of the ruins and labyrinths, the heroes of our texts, however, not only realize the extent of the damage and destruction they have to cope with, they also discover, as has already been mentioned, certain 'treasures', things that have always been there but have hardly been noticed, things that the Satans have been trying to conceal all the time or that have been buried somewhere deep down in former times. Heroes having lost their individuality gain fun if they succeed to raise the Treasures, and they do succeed as soon as they manage to overcome the 'imperative' of individuality, originality, or authenticity, which, from the age of Romanticism onwards, had restricted the possibilities of everyone who wanted to be solely 'himself', i.e., as individualistic as possible. A writer, e.g., had to find his very own, his individual style, and therefore the literary heritage had taken on for him the character of an 'aesthetic Index librorum prohibitorum' $; 40$ he was obliged to somehow stand out from it, to improve or surpass it. ${ }^{41}$ The same holds true for the ideologies of nationalism which also were formulated in the periods of romanticism. They, too, forced a nation to find a distinctive identity, an individual self with its own origins, its own customs, its own 'national personality', differing in all respects from that of the others. Here, too, certain aspects of the heritage became excluded and stigmatized.

\section{FUN GAINED - SOME FREQUENT MOTIFS}

Once one has freed oneself, however, from these ideological=fictional constraints, the horizon opens up to unlimited possibilities. There are all sorts of Treasures waiting to be raised and then enjoyed. In our texts (as in contemporary non-Oriental literature), it can be sheer sexual pleasure or at least the pleasure of talking freely about sexual matters this is why literature has come to display a number of highly porno-

\footnotetext{
${ }^{40}$ Manfred Fuhrmann, Der europäische Bildungskanon des bürgerlichen Zeitalters (Frankfurt: Insel, 1999), quoted in Lesart 4 (1999): 3ff. ('Literaturkanon: Manfred Fuhrmann zur Geschichte des bürgerlichen Bildungskanons'), here 79.

${ }^{41}$ Cf., e.g., Thomas Anz, 'Vorschläge zur Grundlegung einer Soziologie literarischer Normen', Internationales Archiv für Sozialgeschichte der deutschen Literatur 9 (1984): 128-44, here 129; Douwe W. Fokkema, 'The Canon as an Instrument for Problem Solving', in János Riesz, Peter Boerner, and Bernhard Scholz, eds., Sensus Communis: Contemporary Trends in Comparative Literature (Tübingen: Narr, 1986), 245-54. See also the entry 'Originalität' in Metzler Lexikon, 408-9.
} 
graphic, for some even obscene, features. ${ }^{42}$ It can be the pleasure of story-telling itself, naive, simple and completely natural, free of all constraints - this is why many texts are told as if by a traditional storyteller sitting in a market-place or a café. ${ }^{43}$ In some cases, however, it is just the contrary of the quasi-naive narrative: a tendency towards what Jean Fontaine calls an écriture hermétique. ${ }^{44}$ The Treasure may be detected also in language - therefore the spectrum of linguistic expression stretches from underground slang through older forms of the language (in Turkey this is often Ottoman ${ }^{45}$ ) to a delicate poetical tone. ${ }^{46}$ Very often the Treasure also consists of the past and/or of history. This is noticeable in an increase in the number of historical novels ${ }^{47}$ as well as

42 Cf. Kirchner, '»Das Schwarze Buch«', 47, and also my study 'The Function of Sexual Passages in some Egyptian Novels of the 1980s', in R. Allen, H. Kilpatrick, and E. de Moor, eds., Love and Sex in Modern Arabic Literature (London: Saqi Books, 1995), 123-30. In most cases not the whole text but only a few passages serve this purpose; cf., e.g., M. Shukrī's al-Khubz al-häfì (For Bread Alone; [1973] 1982) and Zaman al-akht $\bar{a}^{\supset}$ (The time of errors; ${ }^{2}$ 1992), H. al-Shaykh's Hikāyat Zahra, A. Altan's Dört mevsim, N. Gürsel's Ilk kadın, T. Ben Jelloun's La nuit sacrée, and many others.

${ }^{43}$ Cf., e.g., al-Ghītānī's Risālat al-bașāo ir fì 'l-mașāoir, Ben Jelloun's L'enfant de sable and La nuit sacrée, Tekin's Berci Kristin çöp masalları - to mention only a few out of a much larger number. Ali Nar's Arllar ülkesi is not told by a story-teller, but nevertheless has the form of a fairytale, or parable. In addition, it is endowed with the quality of primeval truth and eternal wisdom, with the help of a short opening section where an unnamed fictional editor declares that the tale about to follow is actually a translation from a manuscript originally written in Arabic by an old and wise Iraqi, whom the fictional editor once happened to meet on a boat tour to Bahrain.

44 Jean Fontaine, 'Du neuf dans le roman égyptien', IBLA 6, no. 181 (1998): 27-47, here $44 \mathrm{ff}$

45 Cf. Kirchner, '»Das Schwarze Buch«', 46. - There are also a number of journals that cultivate an old, exquisite style. For Turkish, e.g., 'kafdağı: Fikir Sanat Edebiyat Dergisi' (Berlin) comes to mind.

46 This is the case, e.g., with al-Kharrāt, and also with the whole qișșaqașìda movement (cf. Lale Behzadi, Die qișșa-qașìda: Übersetzung und Untersuchung ausgewählter Kurzprosa der Sammlungen Madāinu l-bad ${ }^{\circ}$ und Ġawāyātu ż-ẓill von Nāṣir al-Halawān̄i, Hildesheim; Zurich [etc.]: Georg Olms, 1996).

${ }^{47}$ For Turkish, cf. Kirchner, '»Das Schwarze Buch«', 46-47, and also Priska Furrer, 'Rekonstruktion und Reflexion osmanischer Geschichte im Medium der Fiktion: Innovative Tendenzen des historischen Romans am Beispiel von Nedim Gürsel's Boğazkesen', Asiatische Studien 52 (1998): 1103-22, as well as 
in texts set in a nostalgic atmosphere, ${ }^{48}$ and in memoirs. ${ }^{49}$ It is also to be seen in the repeated evocation of abilities thought to have been a source of strength or prosperity in former times. ${ }^{50}$ And there are also the

ead., 'Die literarische Rückgewinnung von Geschichte: Bilder der osmanischen Vergangenheit in modernen türkischen Romanen', Zeitschrift für Türkeistudien 1999, no. 1: 73-91. In North Africa, Assia Djebar, herself a historian, combines personal history with explorations into the history of her country, Algeria, in L'amour, la fantasia (Love, Fantasia, 1985); in Arabic literature it was perhaps al-Ghīțānīs al-Zaynī Barakāt (1974) that paved the way for the new historically-oriented trend, although al-Zaynī itself can not yet be considered a document of a Malistic experience.

${ }^{48}$ For Turkish literature, cf., e.g., Kirchner who mentions 'the literary rediscovery of the world of İstanbul's Beyoğlu quarter' with all the 'poetry of this almost completely vanished universe' ('»Das Schwarze Buch «', 45). For

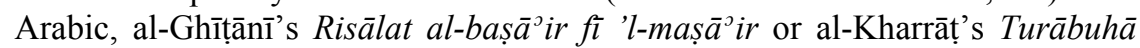
$z a^{c}$ farān may serve as good examples of a nostalgia that not only determines what is narrated but also how it is told, i.e., nostalgia influences not only the contents but also the style of writing.

${ }^{49}$ Cf., among many others, M. Shukrī's al-Khubz al-häfí and Zaman al$a k h t \bar{a}^{s}$, al-Kharrāț's Turābuhā za farān, or the autobiographical sections/layers of A. Djebar's L'amour, la fantasia, as well as N. Gürsel's Ilk kadln and Boğazkesen (The Conqueror; 1995).

${ }^{50}$ In Ali Nar's Arllar ülkesi, the Bees become capable of organizing resistance against the Snakes after having recalled former virtues, which had been preserved in at least a few of them, despite the brain-washing (= identity destruction) the Snakes had operated on them. Once this 'treasure' is detected, hope in the restorability of the initial paradisiacal state of a 'prestabilized harmony' (in the Leibnizian sense) is regained, and with it the energies to fight the enemy. In secret, they elect a new king of their own who, with the help of an old and very wise bee, orders his followers to produce more children, to secretly emigrate in small quantities to a neighboring island, to instruct and train there a liberation army of volunteers ready to give their lives when the Isle of the Bees will finally be recaptured. And this is what, after long years of careful preparation, finally happens. Thousands of young fid $\bar{a}^{\jmath}$ iyyin fighters coming from the neighboring island cross the borders of the land that they, having been brought up in exile, have never seen, but know is theirs. They attack the Snakes which their instructors had described to them and eventually win the fierce battle. Now the Isle of the Bees is again free, and everyone thanks God and enjoys again the peace and harmony in which their ancestors had lived. I consider this novel a Fun Gained text too, because not only are freedom and independence successfully reclaimed, but because the final parts of the novel also celebrate the triumph and joy that victory and the new life grant them. Essentially, however, the Resultative component of this novel consists of the 
Treasures of mysticism, ${ }^{51}$ a love of the mysterious, and the exotic, but also of everyday culture, of marginal sub-cultures, ${ }^{52}$ of popular practices, of lived biculturalism,,$^{53}$ and so on.

The newly gained fun is expressed in most texts as a free play that ignores all 'rules of the art', or boundaries ${ }^{54}$. The new identity is not sharply outlined and limited, but, by its openness, irregularity, and its very unoriginality, has become extremely rich, colorful and lively. Occasionally it seems that this is also reflected in the length of the texts. Because of the pleasure their authors obviously draw from dwelling on every slight detail and their unbridled narrative energy, the books apparently get thicker. But many of them also do not necessarily want to be

re-establishment, in the name of God, of the old harmony and the promise that it will then last to all eternity, guaranteeing a happy life in refah ve emniyet, i.e., 'prosperity and security'.

${ }^{51}$ For Arabic, al-Ghīṭānī's Kitāb al-tajalliyāt (The book of revelations; 3 vols.: 1983, 1985, 1986) is a fine example; cf. Rotraud Wielandt, 'Mystische Tradition und zeitgenössische Wirklichkeitserfahrung in Ğamāl al-Ġīṭānī’s Kitāb at-tağalliyāt', Asiatische Studien/Etudes Asiatiques 50 (1996): 491-523, as well as ead., 'Mystical and Mythical Journeys in Two Novels by Jamāl alGhītān̄̄', in A. Neuwirth et al., eds., Myths, Historical Archetypes and Symbolic Figures, 467-80. For Turkish, it may suffice to mention O. Pamuk's allusions to mystical literature in Kara kitap or Yeni hayat; the journal kafda $\breve{g}_{l}$ with its title's reference to the mystical Kāf mountain is also a typical example.

52 Cf. again, e.g., Shukrī's al-Khubz al-hâafì and Zaman al-akhțā for Arabic. Several Turkish texts with similar tendencies, among them Metin Kaçan's A Roman (The heavy novel, 1990), are described by Kirchner as a 'play with a code that [consciously and on purpose] breaks the rules of modern standard Turkish' ('»Das Schwarze Buch«', 46). Mention must also be made of L. Tekin's Berci Kristin çöp masallarl, which takes the reader to the communities of Turkey's gecekondu inhabitants, the people living on the 'garbage hills'.

$53 \mathrm{Cf}$. the literary output of Turkish writers living in Germany, North Africans living in France, etc., as well as Arabs from the Mashriq in London or the United States. One of the novels of this kind that I liked most is Le the au harem d'Archi Ahmed (Tea in the Harem; 1983) by Mehdi Charef.

54 In A. Nar's Arllar ülkesi, the opening sections, which are told from the perspective of the narrator, who has already been able to raise the Treasure from among the Ruins, and which hence belong to the Resultative component, take on a very playful character. The author here indulges in letting his fantasy flow freely; for instance, he does not content himself with describing, quite in detail, the vocabulary of the bees' language, but also reproduces some of the 'characters' they use for communication: in the narrative some funny squiggles are interspersed. 
read from the first to the last page. The reader, too, is allowed to take his reading duties easy with those 'fat tomes'. Many of them may be opened just as we enter a homepage in the World Wide Web and then start free surfing, following one link to the next; those who think they should somehow master the Web and reach an overview are lost, but those who do not strive for mastery may just have their fun. ${ }^{55}$

Table 2 (next page) tries to summarize the findings of our reading of post-1980 Middle Eastern and North African novels. For many readers of this study, the elements I have mentioned above and listed in the table probably are already well-known 'facts', lacking the quality of new findings, i.e., of originality. They are right. The study itself bears the characteristics of a Malistic text. Most of its ideas being mere quotations from earlier research, by me as well as by others, I had to face the depressing Actuality of a loss of individuality. A closer examination of the Ruins of originality, however, made me detect something that has survived undamaged: the breakdown of the illusion that scholarly discoveries have a purely individual authorship. And I had great fun putting together the various findings that are either not my own or not new anymore into a theoretical framework that likewise is not mine, but a borrowing, a copy. In this way I produced something that may appear to be too multifaceted and rather disorderly, combining Turkish with Arabic, Arabophone Mashriq with Francophone Maghreb authors, and all of this together with a theoretical approach borrowed from studies in German literature. But it is in and of itself the putting together of the many elements by which not only fun is gained, but also additional knowledge. One of the most important conclusions I myself draw out of these findings, especially the contradiction-free applicability of Falk's system to Middle Eastern literatures, is that the way life is perceived in these regions at the end of the twentieth century obviously does not differ fundamentally from how it is experienced in the West; there is a global discursive community with similar outlooks on life on both sides, rather than a 'clash of civilisations'.

${ }^{55}$ Cf. Priska Furrer, 'Literatur und Hypertext: Nicht-Linearität im Kara Kitap des türkischen Autors Orhan Pamuk,' Studia Iranica, Mesopotamica et Anatolica 1 (1994): 167-77. 
Potentiality

Discovery of a surviving

Treasure

- sexuality

- story-telling, entertainment

- language: underground idioms, dialects, sociolects, minority languages, old languages (Ottoman), poetry, ...

- history / memoirs

- everyday culture, marginal sub-cultures, folklore, biculturalism

Raising the 'treasure' =

- overcoming the 'imperative' of individuality, originality, or authenticity

Process of discovery $=$ often

- journey/‘journey’ (fig.)

\section{ACTUALITY}

Ruins of a House, Destroyed Home

- 'deserts', 'labyrinths', 'hells' (cities; memories of the past; the present world; ...)

- loneliness, the individual's forlornness in modern societies, in modernity as a whole

- logical irritation, lack of coherence incl. doubtfulness of ontological status real/ fictional

- 'hell' of lost/destroyed/false/split identity, fragmented self

- 'hell' of lost/prevented individuality, unoriginality, unauthenticity, being a copy, only a successor, de-individualization through ideology

The Evil, Devils, Satans

- $\quad$ snakes, Death, Time, an almighty fatherpatriarch, an alter ego or twin, representatives of the cultural, esp., literary heritage (predecessors), writer'creators'

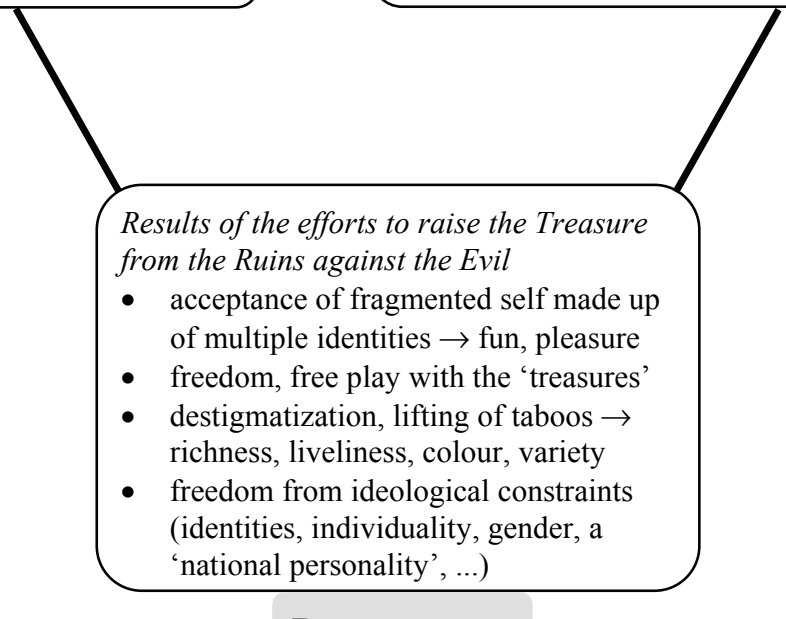

\section{RESUlTATIVITY}

Table 2. Distribution of recurring themes of texts from Turkey, Maghreb and Mashriq on components of Malistic PAR structure 


\section{BIBLIOGRAPHY}

\section{THE TEXTS 56}

Altan, Ahmet. Dört mevsim sonbahar. İstanbul: Can, 1982, ${ }^{4} 1991$.

Ben Jelloun, Tahar. L'enfant de sable. Paris: Éd. du Seuil, 1985. English trans. Alan Sheridan, The Sand Child (San Diego: Harcourt Brace Jovanovich, 1987; and Baltimore: John Hopkins UP, 2000). German trans. Christiane Kayser, Sohn ihres Vaters, rororo 12302 (Reinbek: Rowohlt, 1989).

La nuit sacrée. Paris: Éd. du Seuil, 1987. English trans. Alan Sheridan, The Sacred Night (San Diego: Harcourt Brace Jovanovich, 1989; and Baltimore: John Hopkins UP, 2000). German trans. Eva Moldenhauer, Die Nacht der Unschuld, rororo 12934 (Reinbek: Rowohlt, 1991).

Charef, Mehdi. Le thé au harem d'Archi Ahmed. Paris: Mercure de France, 1983. English trans. Ed Emery, Tea in the Harem (London: Serpent's Tail, 1989). German trans. Christel Kauder, Tee im Harem des Archimedes (Freiburg i.Br.: Beck \& Glückler, 1986).

Djebar, Assia. L'amour, la fantasia. [Paris]: J. C. Lattès, 1985. German trans. Inge M. Artl, Fantasia, Unionsverlag TB 31 (Zurich: Unionsverlag, 1990).

al-Ghīṭānī, Gamāl. Khiṭaṭ al-Ghīṭānī. Beirut: Dār al-Masīra, 1981.

—. Kitāb al-tajalliyāt. Vol. 1, Cairo: Dār al-Mustaqbal al- ${ }^{\mathrm{c}}$ Arabī, 1983; vol. 2, ibid., 1985; vol. 3, ibid., 1986.

—. Risālat al-bașă ir fì 'l-mașā $\bar{a}^{\jmath}$ ir. Riwāyāt al-Hilāl 482. [Cairo]: Dār al-Hilāl, 1989.

Gubayr, ${ }^{\mathrm{C}}$ Abduh. Tahrīk al-qalb. Cairo: Dār Alif Yā̄o 1982.

Gürsel, Nedim. Boğazkesen: Fatih'in romanı. Istanbul: Can, 1995, ${ }^{5}$ 1997. German trans. Ute Birgi, Der Eroberer, Meridiane 12 (Zurich: Amman, 1998).

- Kadinlar kitabi. Istanbul: Cem, 1983; Can, ${ }^{3} 1994$. For translations of the story Ilk kadın, see n. 26 above.

Ibrāhīm, Șuncallāh. Dhāt. Cairo: Dār al-Mustaqbal al-' Arabī, 1992. English trans. Anthony Calderbank, Zaat (Cairo; New York: American University in Cairo Press, 2001). French trans. Richard Jacquemond,

\footnotetext{
56 Where more than one edition of the original is given, it is the last one to which I refer in quotations.
} 
Les années de Zeth, Mondes arabes (Arles: Actes Sud, 1993); my own translation (into German) of chap. 15 is in preparation for an anthology on bureaucracy satires in modern literatures of the Middle East.

- Al-Lajna. Beirut: Dār al-Kalima li'1-Nashr, 1981. 2nd ed. Cairo: Maṭu $\bar{c}^{\mathrm{c}} \bar{a} t$ al-Qāhira, 1982. English trans. Marie St. Germain and Charlene Constable, The Committee (Syracuse: Syracuse University Press, 2001). French trans. Yves Gonzalez-Quijano, Le Comité (Arles: Actes Sud, 1992). German trans. Hartmut Fähndrich, Der Prüfungsausschuss (Basel: Lenos, 1987).

Jabrā, Jabrā Ibrāhīm. Al-Ghuraf al-ukhrā. Beirut: al-Muªssasa al'Arabiyya li'l-Dirāsāt wa'l-Nashr, 1986. French trans. (and ed. of the Arabic text) by Luc-Willy Deheuvels, La quarantième pièce, Bilingues L\&M 4 (Paris: Langues \& Mondes/L'Asiathèque, 1997); German trans. Heiko Wimmen, Das vierzigste Zimmer (Basel: Lenos, 1999).

Jabrā, Jabrā Ibrāhīm \& ${ }^{\mathrm{c}}$ Abd al-Raḥmān Munīf. ${ }^{c} \bar{A} l a m$ bi-lā kharāint. Beirut: al-Mu ${ }^{\circ}$ assasa al- ${ }^{\mathrm{c}}$ Arabiyya li'l-Dirāsāt wa'l-Nashr, 1982, ${ }^{2} 1992$.

Kaçan, Metin. Ăgır roman. N.p: n.p. [?], 1990; Istanbul: Metis, ${ }^{4} 1991$.

Karasu, Bilge. Gece. Istanbul: Metis, 1985, ${ }^{2} 1992$. English trans. Güneli Gün (with the author), Night (Baton Rouge: Louisiana State UP, 1994).

al-Kharrāt, Edward (Idwār). Turābuhā za farān. Dār al-Ādāb. Cairo: Dār al-Mustaqbal al- ${ }^{\mathrm{c}}$ Arabīi, 1985, ${ }^{2}$ 1991. English trans. Frances Liardet, City of Saffron (London: Quartet, 1989). German trans. Hartmut Fähndrich, Safranerde (Basel: Lenos, 1990).

Khūrī, Ilyās. Rihlat Ghāndī al-șaghīr. Beirut: Dār al-Ādāb, 1989. English trans. Paula Haydar, The Journey of Little Gandhi (Minneapolis: Minnesota UP, 1994). French trans. Luc Barbulesco, Le petit homme et la guerre: le voyage du petit Gandi (Paris: Éd. Arléa, 1995).

Kür, Pınar. Bir cinayet romani. Istanbul: Can, 1989, ${ }^{3} 1990$.

Nar, Ali. Arılar ülkesi. Istanbul: Gonca, 1994.

Pamuk, Orhan. Beyaz kale. Istanbul: Can, 1985, ${ }^{9} 1992$. English trans. Victoria Holbrook, The White Castle (New York: Braziller, 1991). German trans. Ingrid Iren, Die weiße Festung, Frankfurt/M.: Insel, 1990 .

Kara kitap. Istanbul: Can, 1990, ${ }^{14} 1992$. English trans. Güneli Gün, The Black Book (New York: Farrar, Straus \& Giroux, 1994; and San Diego: Harcourt Brace \& Co., 1996). German trans. Ingrid Iren, Das schwarze Buch (Munich [etc.]: Hanser, 1995).

—. Sessiz ev. Istanbul: Can, 1983, ${ }^{7} 1991$. 
Yeni hayat. Istanbul: İletişim, 1994. English trans. Güneli Gün, The New Life (New York: Farrar, Straus \& Giroux, 1997; and Vintage Books, 1998). German trans., Das neue Leben (Vienna: Hanser, 1998).

al-Shaykh, Ḥanān. Hikāayat Zahra. Beirut: Dār al-Ādāb, 1980, ${ }^{2} 1989$. English trans. Peter Ford, The Story of Zahra (London \& New York: Quartet, 1986, ${ }^{3}$ 1993). French trans. Yves Gonzalez-Quijano, Histoire de Zahra ([Paris]: J. C. Lattès, 1985). German trans. Veronika Theis, Sahras Geschichte (Basel: Lenos, 1989).

Shukrī, Muhammad. Al-Khubz al-hâffi. Casablanca: by the author, 1982; 2nd ed. Tanja: n.p., 1983; 3rd ed. London/Beirut: Dār al-Sāqī, 1993. English versions after the first ed. Paul Bowles, For Bread Alone (London: P. Owen, [1973]; London: Grafton, 1987; and Saqi Books, 1993). French trans. Tahar Ben Jelloun, Le pain nu (Paris: Maspero, [1996]). German trans. Georg Brunold and Viktor Kocher, Das nackte Brot (Munich; Zurich: Piper, 1992).

. Zaman al-akhța $\bar{a}^{\supset}$ : Sìra dhātiyya-riwā̄iyya. [Al-Dār al-Bayḍā̄o]: Maṭba ${ }^{c}$ at al-Najāḥ al-Jadīda, ${ }^{2} 1992$. French trans. Mohamed El Ghoulabzouri, Le temps des erreurs (Paris: Éd. du Seuil, 1994). German trans. Doris Kilias, Zeit der Fehler (Frankfurt/M.: Eichborn, 1994).

Tekin, Latife. Berci Kristin çöp masalları. Istanbul: Adam, 1984 [or 1985?]; 2nd ed. Istanbul: Metis, 1990, ${ }^{6} 1991$. English trans. Ruth Christie and Saliha Paker, Berji Kristin: Tales from the Garbage Hills (London \& New York: Marion Boyars, 1993). German trans. Harald Schüler, Der Honigberg (Hamburg: Galgenberg, 1987; and Zurich: Unionsverlag, 1993).

Wellershoff, Dieter. Die Sirene. Cologne: Kiepenheuer \& Witsch, 1980.

\section{REFERENCES}

Anz, Thomas. 'Vorschläge zur Grundlegung einer Soziologie literarischer Normen', Internationales Archiv für Sozialgeschichte der deutschen Literatur 9 (1984): 128-44.

Arabische Literatur, postmodern. Ed. Andreas Pflitsch, A. Neuwirth, B. Winckler. Munich: edition \& kritik, 2004.

Behzadi, Lale. Die qișsa-qașìda: Übersetzung und Untersuchung ausgewählter Kurzprosa der Sammlungen Madā`inu 1-bad ${ }^{\circ}$ und Gawāyātu z-ẓill von Nāṣir al-Halawānī. Hildesheim; Zurich [etc.]: Georg Olms, 1996.

Esen, Nüket, ed. Kara kitap üzerine yazllar. Istanbul: Can Yayınları, 
1992.

Falk, Walter. Handbuch der literarwissenschaftlichen Komponentenanalyse: Theorie, Operationen, Praxis einer Methode der neuen Epochenforschung. Beiträge zur neuen Epochenforschung 3. Frankfurt/Main, etc.: Lang, 1983. New rev. edition: Handbuch der Komponentenanalyse: Erschließen von Sinn in Text und Epoche. Taunusstein, etc.: Vlg. Werner Imhof, 1996.

- Die Ordnung in der Geschichte: Eine alternative Deutung des Fortschritts. Sachsenheim [etc.]: Burg Vlg, 1985.

—. 'Das Sinnsystem der gegenwärtigen Periode: Präzisierungen der bisherigen Deutung (Zusammenfassung)'. Paper presented to the annual meeting of the MKE (Marburger Kreis für Epochenforschung), 16 Sept. 1996.

- Václav Havels Briefe aus dem Gefängnis: Wo der Mensch zu Hause ist - ein Dialog. Taunusstein: VerlagMar, 1994.

- 'Die Wiederentdeckung christlicher Problemzusammenhänge in der deutschen Dichtung seit 1980'. Paper given at the 1997 annual meeting of the MKE group.

Fokkema, Douwe W. 'The Canon as an Instrument for Problem Solving'. In János Riesz, Peter Boerner, and Bernhard Scholz, eds., Sensus Communis: Contemporary Trends in Comparative Literature, 245-54 (Tübingen: Narr, 1986).

Fontaine, Jean. 'Du neuf dans le roman égyptien', IBLA 6, no. 181 (1998): 27-47.

Fuhrmann, Manfred. Der europäische Bildungskanon des bürgerlichen Zeitalters. Frankfurt: Insel, 1999.

—. 'Literatur und Hypertext: Nicht-Linearität im Kara Kitap des türkischen Autors Orhan Pamuk'. Studia Iranica, Mesopotamica et Anatolica 1 (1994): 167-77.

Furrer, Priska. 'Die literarische Rückgewinnung von Geschichte: Bilder der osmanischen Vergangenheit in modernen türkischen Romanen'. Zeitschrift für Türkeistudien 1999, no. 1: 73-91.

_ ' 'Literatur und Hypertext: Nicht-Linearität im Kara Kitap des türkischen Autors Orhan Pamuk', Studia Iranica, Mesopotamica et Anatolica 1 (1994): 167-77.

'Readers as Writers, Fiction as Theory, and Other Confusions: The Metafictional Trickery of Bilge Karasu and Pınar Kür'. In S. Guth, P. Furrer, and J. C. Bürgel, eds., Conscious Voices: Concepts of Writing in the Middle East (Beirut: Orient-Institut; Stuttgart: Steiner, 1999), 51-68. 
'Rekonstruktion und Reflexion osmanischer Geschichte im Medium der Fiktion: Innovative Tendenzen des historischen Romans am Beispiel von Nedim Gürsel's Boğazkesen'. Asiatische Studien 52 (1998): 1103-22.

Guth, Stephan. Brückenschläge: Eine integrierte 'turkoarabische' Romangeschichte (Mitte 19. bis Mitte 20. Jhdt.). Literaturen im Kontext 14. Wiesbaden: Reichert Verlag, 2003.

- 'The Function of Sexual Passages in Some Egyptian Novels of the 1980s'. In R. Allen, H. Kilpatrick, and E. de Moor, eds., Love and Sex in Modern Arabic Literature (London: Saqi Books, 1995), 123-30.

. 'Post-Modernism, Apoliticality, "Settling Accounts": On Ahmet Altan's Dört Mevsim Sonbahar'. In S. Guth, P. Furrer, and J. C. Bürgel, eds., Conscious Voices: Concepts of Writing in the Middle East (Beirut: Orient-Institut; Stuttgart: Steiner, 1999), 107-19.

- 'The Simultaneity of the Non-Simultaneous: The Global Dimensions of Middle Eastern Literature (esp. in the 19th Century)'. In Chr. Szyska and F. Pannewick, eds., Crossings and Passages in Genre and Culture, Literaturen im Kontext 15 (Wiesbaden: Reichert Verlag, 2003), 121-37.

- A World Full of Secrets. The Hero as Detective in Two Novels from Egypt and Turkey. Lecture given in 1994 and published in booklet form as Beirut Zokak el-Blat(t) [= Occasional Papers of the German Institute of Oriental Studies in Beirut], no. 2, May 1996.

_ Zeugen einer Endzeit: Fünf Schriftsteller zum Umbruch in der ägyptischen Gesellschaft nach 1970. Islamkundl. Untersuchungen 162. Berlin: Schwarz, 1992.

-. 'Zwei Regionen - eine Literaturgeschichte? Zwei zeitgenössische Romane aus Ägypten und der Türkei und die Möglichkeit einer übergreifenden Periodisierung nahöstlicher Literaturen'. Die Welt des Islams 34 (1994): 218-45.

Karakaşoğlu, Yasemin. Fünf Stimmen im lautlosen Haus: Geschichte, Zeit und Identität im türkischen Gegenwartsroman am Beispiel von 'Sessiz Ev' von Orhan Pamuk. Wiesbaden: Harrassowitz, 1993.

Kindlers Neues Literatur Lexikon. Ed. Walter Jens (Studienausgabe der Originalausgabe 1988-92). 20 vols. München: Kindler, [n.d.].

Kirchner, Mark. '»Das Schwarze Buch«: Orhan Pamuk und die türkische Postmoderne'. In Konrad Meisig, ed., Orientalische Erzähler der Gegenwart: Vorträge und Übersetzungen der Mainzer Ringvorlesung im Sommersemester 1998 (Wiesbaden: Harrassowitz, 1999), 43-63. 
Metzler Lexikon Literatur- und Kulturtheorie: Ansätze, Personen, Grundbegriffe. Ed. Ansgar Nünning. Stuttgart; Weimar: J. B. Metzler, 1998. al-Nowaihi, Magda. 'Memory and Imagination in Edwar al-Kharrat's Turābuhā zacfarān,' in JAL 25 (1994): 34-57.

Pflitsch, Andreas. 'Narration against Transitoriness and Temporality: Mythical Time Structure in Idwār al-Kharrāṭ's Works'. In Angelika Neuwirth et al., eds., Myths, Historical Archetypes and Symbolic Figures in Arabic Literature: Towards a New Hermeneutic Approach (= Proceedings of the International Symposium in Beirut, June 25th June 30th, 1996), Beiruter Texte und Studien 64 (Beirut: OrientInstitut; Stuttgart: Steiner, 1999), 363-78.

Wielandt, Rotraud. 'Mystische Tradition und zeitgenössische Wirklichkeitserfahrung in Ǧamāl al-Gīịānī’s Kitāb at-tağalliyāt'. Asiatische Studien/Etudes Asiatiques 50 (1996): 491-523.

- 'Mystical and Mythical Journeys in Two Novels by Jamāl alGhītānī'. In A. Neuwirth et al., eds., Myths, Historical Archetypes and Symbolic Figures in Arabic Literature: Towards a New Hermeneutic Approach (= Proceedings of the International Symposium in Beirut, June 25th - June 30th, 1996), Beiruter Texte und Studien 64 (Beirut: Orient-Institut; Stuttgart: Steiner, 1999), 467-80.

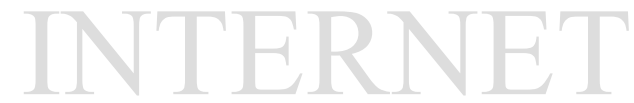

